Franco P.L.J. ${ }^{1}$

Longarezi A.M. ${ }^{2}$

de Marco F.F. ${ }^{3}$

\section{MOTIVES IN BRAZILIAN SCHOOL EDUCATION ACCORDING TO THE CULTURAL HISTORICAL PERSPECTIVE AND THE DEVELOPMENTAL EDUCATION APPROACH*}

1) University of State of Minas Gerais (UEMG), Minas - $8^{\circ}$ andar, Rod. Papa João Paulo II, 4143 - Serra Verde, Belo Horizonte, Minas Gerais, 31630-340, Brazil, E-mail: patricia.jfranco11@gmail.com

2) Federal University of Uberlândia (UFU), João Naves de Ávila, 2121, Santa Monica of Uberlandia, Minas Gerais, 38408-100, Brazil E-mail: andrea.longarezi@gmail.com

3) Federal University of Uberlândia (UFU), João Naves de Ávila, 2121, Santa Monica of Uberlandia, Minas Gerais, 38408-100, Brazil

E-mail: ffmarco@gmail.com

\begin{abstract}
The article investigates the concepts "motive" and "activity", according to Leontiev's constructs and the didactic-formative intervention research. The didactic-formative intervention research consists in a research methodology created and developed in Brazil by Longarezi in 2012-2014 within GEPEDI/UFU, for the accomplishment of developmental education investigations. This kind of research is based on the principles of developmental education and, therefore, has as an objective-goal the development of students for the learning activity (objective-means). In the relation to the procedure, the investigation is divided into four stages: 1) diagnostics of the processes of teaching-learning-development of the current school systems; 2) formative intervention with teachers; 3) educational intervention with students; and 4) systematization and analysis of didactic principles for teaching that trigger development. The analysis was conducted according to the Cultural Historical perspective and the developmental education. An elementary school teacher of Mathematics had participated in the research together with 21 eighth and ninth grade students of a public school in the State of Minas Gerais, Brazil.
\end{abstract}

Key words: L.S. Vygotsky; A.N. Leontiev; Brazil; motive; activity; cultural historical theory; developmental education.

\section{Франко П.Л.Ж. ${ }^{1}$ \\ Лонгарези А.М. ${ }^{2}$ де Марко Ф.Ф. ${ }^{3}$}

\section{СТИМУЛИРОВАНИЕ ОБРАЗОВАНИЯ В БРАЗИЛЬСКОЙ ШКОЛЕ НА ОСНОВЕ КУЛЬТУРНО-ИСТОРИЧЕСКОЙ КОНЦЕПЦИИ И ИДЕЙ РАЗВИВАЮЩЕГО ОБУЧЕНИЯ}

\footnotetext{
1) Университет штата Минас Жерайс, ул. им. Папы Иоанна Павла II, 4143 - Серра Верде, г. Белу-Оризонти, штат Минас Жерайс, 31630-340, Бразилия, E-mail: patricia.jfrancol1@gmail.com

2) Федеральный университет Уберландии, ул. Јоão Naves de Ávila, - Санта Моника, 2121, г. Уберландия, штат Минас-Жерайс, 38408-100, Бразилия E-mail: andrea.longarezi@gmail.com

3) Федеральный университет Уберландии, ул. Јоão Naves de Ávila, - Санта Моника, 2121, г. Уберландия, штат Минас-Жерайс, 38408-100, Бразилия E-mail:ffmarco@gmail.com
}

${ }^{*}$ Special thanks to the research group GEPEDI (Study Group in Developmental Education and Teacher Professional Development), and FAPEMIG. 


\begin{abstract}
Аннотация
В статье рассматриваются понятия «мотив» и «деятельность» в свете учения А.Н. Леонтьева о деятельности, и результаты исследования дидактико-созидательного внедрения. Дидактико-созидательное внедрение включает методологию, созданную и разработанную в Бразилии А. Лонгарези в 2012-2014 в лаборатории GEPEDI/UFU, для проведения исследований в области развивающего обучения. Подобные исследования основаны на принципах развивающего обучения и направлены на развитие студентов для учебной деятельности (цель-средства). В связи с этим в исследовании выделено четыре этапа: 1) диагностика процессов обучение-учение-развитие в современной школьной системе; 2) созидательное внедрение с учителями; 3) образовательное внедрение со студентами; 4) систематизация и анализ дидактических принципов, способствующих развитию. Анализ проводился в соответствии с культурно-исторической концепцией и идеями развивающего обучения. В эксперименте принимали участие учитель математики в начальной школе и 21 ученик восьмого и девятого классов государственной школы в штате Минас-Жерайс, Бразилия.
\end{abstract}

Ключевые слова: Л.С. Выготский; А.Н. Леонтьев; Бразилия; мотивация; деятельность; культурно-историческая концепция; развивающее обучение.

\section{Introduction}

The study derived from the investigation of the following questions: Is it possible to establish different relations in the internal structure of activities (study and teaching), given the context of Brazilian public schools? Which didactic and formative actions would be required for the establishment of more favorable relations in what concerns the development of motives that form the meaning of such activities?

\section{Main part}

Motive as an orientation element in the Activity Theory

In the context of Brazilian educational reality, the term "motive" is frequently employed to demonstrate something exclusively related to the subject, something independent from social relationships and the sociocultural context. A usual and commonsense translation to the term is "will". However, in scientific literature it can acquire several connotations, occasionally different from common sense and having multiple interpretations, definitions and conceptualizations, according to the corresponding theory.

The concept "motive" has been used as an orientation element, according to Alexei Nikolaevich Leontiev's Activity Theory. In this specific sense, motive is related to the complex activity an individual undertakes in conditions of collective work. Leontiev explains that the condition of activity puts human beings in a com- pletely different relation in comparison to an animal, to such an extent that they create connections and social relations - elements that orient the individual towards the accomplishment of actions and collective work. The meaning of a given action is linked to the social relations and conditions the individual establish in a certain collective context [11]. Thus, what moves the subject is intrinsically related to his position as a member of a given collectivity.

Therefore, an action depends on the connections the individual establishes with the collective, on the needs generated in this context, on the conditions one has to reach these objectives, and on a certain direction. The social relationships established in a collective human activity generate needs specifically human and actions that are capable of addressing them - or not. The actions will only make sense to those performing them, if the "subject realizes the connection between the object [content] of an action, its goal, and the generator of the activity, its motive" [3, p. 80]. The relation, thus, is motive-objective-object (content). To our understanding, when there is a conscious goal to an action the subject is provided with a meaning encircling this same action. Consequently, the content of an action cannot be interpreted as the connection between material objects, but as the goal consciously and internally constituted in the action that originated it. 
From this perspective, motives only exist in relation to needs, and these are tied to the activities of a subject, being generated and transformed in the moment of its production. Thus, according to Leontiev [5], the concept of "motive" - present in the psychological analysis of human being's formation of personality - derives from such correlations.

\section{Motives that form meaning and stimuli mo-} tives

In Leontiev sense, motives of human activity are characterized by their variety, and they are differentiated one from another by the kind of need to which they correspond and are divided into natural and superior. Superior needs have a social character and are motivated by the life conditions of the society, as well as by the place occupied by man in a system of social relationships. Such needs can be material (material objects created by social production, put at man's service) and spiritual (aesthetic, ideal objects, such as art, knowledge and culture). For this reason, they are interdependent. Furthermore, "motives are also different in relation to the way their content is manifested - e.g. through images, concepts, thoughts, or ideals" [4. p. 348]. They can display a different relation in what concerns the possibility of being achieved through an activity.

In response to such complex feature of human activity - in which man forms needs and motives in the act of its production - Leontiev [5, p. 119] clarifies that the activity is polimotivated, i.e. can simultaneously respond to two or several motives. Nevertheless, the author states that even though they coexist, they are found in different planes. Leontiev elucidates that although motives do not transform into others, they are capable of fulfilling different functions in the same activity. To our understanding, this feature holds both the problem and objective of this research. In other words, the integrity of our effort resides in the establishment of new relations in the internal structure of activities - in the context of Brazilian school education - so as to develop new motives and perform the "creator of meaning" function with an enhanced preponderance in the interior of the activities performed by the subjects.

In the study activity, "the motives can be general or partial, as well as psychologically different according to the role they play" [4, p. 346]. For this reason, the general motive can trigger a series of intermediate actions with partial motives - each with a specific objective but they collectively contribute to satisfying the single need that motivated the activity. Consequently, this activity can ultimately be extended to a long time.

It is our understanding that the meaning of an activity is created in the subject according to the way he/she can perform each of the objectives that were set. If these objectives be related to the previously established need, they will equally correspond to the main objective of the activity from which the action belongs. Leontiev [4, p. 347] considers that one of the most important education tasks is to trigger motives for study - that is, to set favorable conditions for the needs to be materialized in the action's goals, i.e. to have a motive set on purposes. Thus, subjects are able to develop motives with the role of providing personal meanings.

According to Leontiev [4, p. 351-5], the most constant motives are those displaying lasting action, being independent of casual situations and more closely situated in the sphere of the meaning which the individual psychologically outlines in view of school activities. This happens because they are related to one's life and personal interests, and not to aims and objectives outlined by others, or socially imposed. Although they are able to coexist in the activity, only the general and broad motives provide a specific meaning to the action in question. Therefore, Leontiev refers to them as motives that form meaning. Due to different translations there are several terminologies for the same concept in Alexei N. Leontiev's works. "Nevertheless, the concept essentially remains the same: motives truly efficient; motives equipped with meaning; motives that truly act; motives that generate meaning; efficient motives and motives that form meaning" [8, p. 8; 28-29]. In the context of 
school education, the social relationships established by teachers and students can have an impact in each other motives. From our understanding, this depends on the place they occupy in the activities system and on the classroom's existing mediations.

This theoretical assumption explains the reason why the particular and narrow motives - e.g. winning awards, getting good grades, not being punished or criticized by parents - coexist with others in the study activity. However, we understand that they play different roles in respect to study. These particular and narrow motives act for a short period of time, according to direct circumstances (parents or teachers attitudes). They stimulate only an immediate action, serving as supplementary stimulus. "These types of motives do not immediately modify the meaning of study, but they eventually stimulate the student to accomplish what he has proposed to achieve" [4, p. 349]. For that reason, they are called stimuli motives. In Leontiev's works there are different terminologies for the same concept. "Nevertheless, the concept essentially remains unchanged: motives only comprehensible; stimuli motives; motives only comprehended and inneficient motives" [8, p. 8]. Since these motives are not directly related to the activity's content and objective, they are not capable of rendering meaning to activities on their own. Functioning as complements, this type of motive can coexist with other motives in most of human complex activities.

Stimuli motives generally overlap the motives that form meaning in both the current school education and the capitalist context. There are many reasons for this, such as curricular structure, types of class contents, teaching methods and instruments, multiple and divergent theoretical perspectives of knowledge, organizational forms of teaching and unidirectional relations. These factors generally do not share the same purpose - integral development of students, thinking and theoretical concept - in a conscious way.
The motive's formation/education movement in the context of Brazilian public school

Based on the understanding of the concept of motive and its relation to human activity more specifically, to teaching and study activities - the research was carried out with a teacher and her students. It enabled to capture students' accounts about how they proceed in learning actions, their processes of satisfying cognitive and affective needs, if these are accomplished or not, and if they are related to content/object (theoretical concepts) of Mathematics; as well as the generated feelings from this actions (if positive or negative).

We have organized for three semesters a formation process based on Moura's [10] Teaching-Orienteering Activity (TOA), which it was structured by systems of learning actions. This process of formation of mental actions and theoretical concepts in algebra enabled the development of appropriations of fractional equation and fractional exponent equation (TA-I), linear and quadratic equation (TA-II) and function (TA-III) concepts. In this movement we have analyzed whether the conceptual need is able to objectify itself in the relation action-object-objectiveoperation. Moreover, we have sought to grasp the resulting volitional-affective manifestations, according to the actions of students' accounts. These conditions provided possibilities of interfering with this formation process and also to capture the story of this development. With the intention of offering the reader an overview of this process, we present a synthesis of the objective and subjective products of the entirety of the systems of learning actions made by students.

From this totality we have highlighted the moments in which the actions demonstrate the revealing moments of a new quality. We have designated this totality "Cognitive and volitional-affectional moment", by system. Let us consider the cognitive and volitional-affective movement, by systems of learning actions in each TA (I-II-III) in the following figure. 


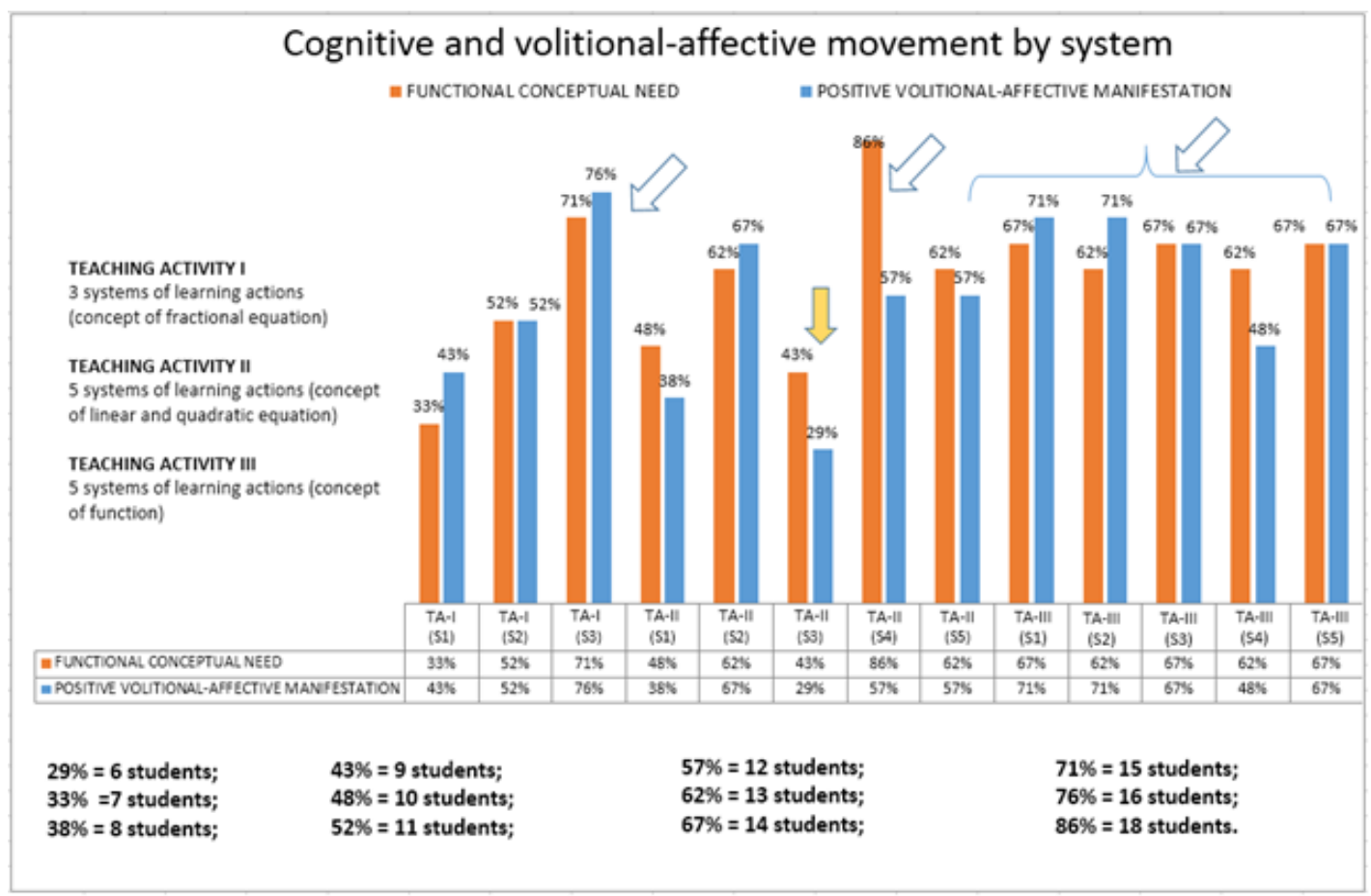

Fig. Cognitive and volitional-affective movement by system [1, P. 212]

Рис. Когнитивное и волево-аффективное движение по системе [1, С. 212]

The arrows with blue outlines indicate the revealing moments when a new quality of actions affects the motives for studying and/or appropriating the concept, which present the correspondence relation of the conceptual need in its object-objective. They also indicate the manifestations of the ability to consciously propose goals for its action, to search and find how to reach them, with justifications of the possibilities of overcoming difficulties. The yellow arrow indicates the moment in which the motiveobject-objective correspondence moves away, and in which the volitional-affective manifestations decay.

The percentage refers to the number of students with motive-object-objective correspondence, by system, in the conceptual functional need axis (blue bars). The red bars indicate the percentage of students with attitudes, feelings, emotions and positive cognitive arguments, by system, in the positive volitional-affective manifestation axis. Students accounts in reference to the accomplished actions demonstrate that, in the process of appropriation of the necessary mode of action to operate with the concept - being aware of its objectives -, they also develop deeper and more complex levels of thought. Fur- thermore, they can assign meaning to the concepts that are thus formed.

In the last system, the cognitive movement is accomplished by $62 \%$ of the students who demonstrate clarity in their own intellectual operations and that these are addressed while conducting learning actions. This indicates that they present the development of characteristic features of theoretical thought. In $71 \%$ of the students we can notice a positive manifestation towards the study, even though some presented difficulties to perform and solve in an independent way. The unity of this movement represents a qualitative development of the function related to the formation of meaning in the study activity.

Considerations about motive's formation/education in TOA

The research displays the didactic-formative intervention in the interrelationships of the internal structural elements of teaching and study activities. The educational movement triggers teaching actions that provide answers to this text's initial questioning. In summary, we can assert that, in the first activity (TA-I), the action of intentionally organizing teaching (in its form and content) is fundamental to what concerns students' learning [2]. This is also the case with 
the action of diagnosing empirical knowledge and previous generalizations about arithmetic and geometry. According to Vygotsky [12, p. 269-270], in the structure of algebraic thought and in the systems of concepts, they are not cancelled, nor lost, but incorporated to one another. Thus, they begin to be part of the new task of thinking.

As an objectification of the first activity, in the second activity (TA-II) the act of promoting the conditions from which the student is able to form theoretical thought is seen as being essential to educational actions, given that the student is aware of both process and product (the concept in its essence).

\section{Conclusion}

The results of this process - as a totality expose the importance of the didactic-formative intervention process to both activities, in order to create new conditions, needs and motives that form meaning, positively manifested in the third activity (TA-III), based on the Cultural-historical perspective and the developmental education, in educational contexts that are regulated under the capitalist democratic system, such as the Brazilian.

\section{Special thanks}

To the research group GEPEDI -Study Group in Developmental Education and Teacher Professional Development - and in a particular of a $\mathrm{PhD}$ research sub-project [1], linked to the projects "Modes and conditions for the execution of developmental education: a formative intervention in teacher education and teacher practice in the context of Brazilian public schools" [7] and "Developmental education in the context of Brazilian public schools: modes and conditions for promoting development" [6[. Both projects were developed in Brazil under the coordination of Professor Andréa Maturano Longarezi, with funding from FAPEMIG (Fundação de Amparo à Pesquisa do Estado de Minas Gerais), CNPq (Conselho Nacional de Desenvolvimento Científico e Tecnológico) - Process $n^{\circ}$ 120084/2016-3, and Capes (Coordenação de Aperfeiçoamento de Pessoal de Nível Superior) Programa Observatório da Educação Básica (OBEDUC).
Информачия о конфликте интересов: авторы не имеют конфликта интересов для декларации.

Conflicts of Interest: authors have no conflict of interests to declare.

\section{References}

1. Franco P.L.J. O desenvolvimento de motivos formadores de sentido no contexto das atividades de ensino e estudo na escola pública brasileira. 2015. 363f. (Thesis) Post-Graduation Program in Education. UFU, MG. $2015 . \quad$ URL: https://repositorio.ufu.br/bitstream/123456789/13690 /1/DesenvolvimentoMotivosFormadores.pdf. (accessed 22.05.2017).

2. Guseva L.G., Sosnowski A.N. Russian Education in Transition: trends at the primary level // Canadian and International Education. 1997, v. 26. №1, Pp. 14-31. URL: http://ir.lib.uwo.ca/cieeci/vol26/iss1/3 (accessed 22.05.2017).

3. Leontiev A.N. O desenvolvimento do psiquismo. Lisbon: University Horizon. 1978.

4. Leontiev A.N., Smirnov A.A., Rubinshtein S.L., Teplov B.M. Las necesidades y los motivos de la actividad. Psicología. Instituto de investigación científica. Traducción directa del ruso por Florencio Villa Landa, Cuba, 1961.

5. Leontiev A.N. Actividad, conciencia e personalidad. Havana: Editorial Pueblo y Educación. 1983.

6. Longarezi A.M. Didática desenvolvimental no contexto da escola pública brasileira: modos e condições para um ensino que promova o desenvolvimento. Brasília, DF: CAPES, Programa Observatório da Educação, Edital 049/2012 (Research Project), 2012.

7. Longarezi A.M. Didática desenvolvimental: intervenções pedagógico-formativas desenvolvedoras de estudantes do Ensino Fundamental, Médio e Superior. Brasília, CNPq, National Council for Scientific and Technological Development (Research Project), 2014.

8. Longarezi A.M., Franco P.L.J. A.N. Leontiev: a vida e a obra do psicólogo da atividade / Longarezi, A.M., Puentes, R.V. Ensino Desenvolvimental: vida, pensamento e obra dos principais representantes russos. V. I. Uberlândia: EDUFU, 2013.

9. Longarezi A.M., Franco P.L.J. A.H. Leont'ev: zhizn' i dejatel'nost' psihologa. Dubna Psychological Journal. Dubna / Russia. 2015. Pp. 9-44. URL: http://psyanima.ru/issues/issues-2015/1-2015/ (accessed 22.05.2017). Russian. 
10. Moura M.O. Controle da variação de quantidades. Atividades de ensino. São Paulo: University of São Paulo. 1996.

11. Shemchuk L.G. Extra-curricula activities in small groups as a factor of moral education of elementary school students. Abstract of the thesis. - M.: Moscow State Pedagogical University, 1991. - 18 p. Russian.

12. Vygotsky L.S. Estudio del desarrollo de los conceptos científicos en la edad escolar. Ch. 6. V. II. Problems of General Psychology. Madrid: A. Machado libros, 2001.

\section{About the authors:}

Franco Patrícia Lopes Jorge, Associate Professor, $\mathrm{PhD}$ in Education
Longarezi Andréa Maturano, Associate Professor, Faculty of Education, Postdoctoral Researcher in Education

de Marco Fabiana Fiorezi, Associate Professor, Faculty of Mathematics, Postdoctora Researcher in Education

Данные авторов:

Франко Патрисия Лопез Жорже, доцент Университета штата Минас Жерайс, кандидат педагогических наук

Лонгарези Андреа Матурано, доцент Педагогического факультета, кандидат педагогических наук

де Марко Фабиана Фиорези, доцент кафедры математики (математической школы), кандидат педагогических наук 